DOI 10.37882/2223-2982.2020.08-2.12

\title{
ФОРМИРОВАНИЕ И ПОХОДНЫЙ МАРШ 4-ГО ПОЛКА НИЖЕГОРОДСКОГО ОПОЛЧЕНИЯ 1812 Г. (СЕНТЯБРЬ 1812 - АПРЕЛЬ 1813 ГГ.)
}

\section{FORMATION AND MARCHING OF THE 2ND REGIMENT OF THE NIZHNY NOVGOROD MILITIA IN 1812 (SEPTEMBER 1812-APRIL 1813) \\ D. Nikolaev \\ F. Dorofeev}

Summary: In this article, on the basis of archival materials of the Central archive of Nizhny Novgorod region (TSANO) discusses issues about the peculiarities of formation of one of the divisions of the Nizhny Novgorod militia in the era of 1812 - 2-d regiment, and, on the basis of the regimental reports, provides information about Hiking the March, coupled with data about numbers, logistics and other information that characterize the «private» episode of fighting for the nomination militia units of the Russian army to the borders of the Russian Empire to further commission of a foreign campaign.

Keywords: Patriotic War of 1812, Nizhny Novgorod militia in 1812 , marching march, weapon, equipment.

\author{
Николаев Дмитрий Андреевич \\ К.и.н., дочент, Нижегородский государственный \\ университет им. Н.И. Лобачевского \\ dmnikolaeff@mail.ru \\ Дорофеев Федор Александрович \\ К.и.н., дочент, Нижегородский государственный \\ университет им. Н.И. Лобачевского \\ feddor70@mail.ru
}

Аннотация: В данной статье на основе архивных материалов Центрального архива Нижегородской области (ЦАНО) рассматриваются вопросы об особенностях формирования одного из подразделений нижегородского ополчения в эпоху 1812 г. - 2-го полка, а также, на основе полковых рапортов, приводятся сведения о его походном марше, вкупе с данными об изменении численного состава, снабжении и прочими сведениями, характеризующими «частный» эпизод боевого выдвижения ополченского подразделения русской армии к границам Российской Империи для дальнейшего совершения заграничного похода.

Ключевые слова: Отечественная война 1812 г., нижегородское ополчение 1812 г., походный марш, оружие, снаряжение.

ный статский советник П.Ф. Козлов [18, с.115]. Среди полномочных структур, созданных специально для этой цели, особо выделялись, по своему значению и функциям, комитеты пожертвований [5, с.95] и вооружения [12, с.58]. Обмундирование [13, с.58], снаряжение и даже вооружение [9, с.75] ополчений той поры осуществлялось за счет «отдатчиков ратников», т.е. помещиков [10, с.345], либо мещанских сообществ [15, с.35]. Все полки нижегородского ополчения входили в состав так называемого III ополченского округа (вместе с ополчениями казанским, вятским, симбирским, пензенским и костромским) под предводительством генерал-лейтенанта П.А. Толстого [7, c.67]. Непосредственным начальником нижегородского ополчения являлся князь Г.А. Грузинский.

4-й пехотный полк под командованием полковника Ф.Ф. Ралля формировался в крупном селе Лыскове из ратников макарьевского, княгининского и лукояновского уездов. Согласно расписанию и декларируемой явке в полк к 1-му сентября назначенного офицерского состава, предполагалось сразу начать прием и сопровождение «партий» воинов на первоначальные сборные места в соответствующих уездных центрах (Макарьеве, Княгинине и Лукоянове) и командировать для этого сотенных и пятидесятных начальников. Но, по докладу Ралля, сразу 
были зафиксированы опоздания офицеров к полку: «по сие число (7 сентября-авт.) явились ко мне батальонные начальники подполковник Воинов, коллежский асессор Стремоухов и пятидесятные Троицкий...Козмин...более же еще никто ко мне не явился...» [22, л.1], а явившийся позднее пятидесятник Косткин, отправленный в Лукоянов для сопровождения набранных ратников на сборное место, вместо этого «...привезен был в Княгинин к тамошнему городничему в самом неблагопристойном виде (был сильно пьян - авт.), имея при себе билет на выдачу лошадей никем не подписанный, который при сем прилагаю...прошу Ваше Сиятельство для прекращения подобных беспорядков и в пример другим выключить господина прапорщика Косткина из 4-го полка...» [22, л.2]. Тем не менее, провинившийся не был «выключен» из полка ввиду слишком очевидного дефицита кадров командного состава.

Согласно донесений Ралля Грузинскому 16 сентября 1812 г. в полк была принята первая партия ратников числом в 300 человек (доставил из Княгинина пятидесятный начальник Козьмин) [22, л.3]; 19 сентября сотенный Карпов доставил 200 чел. (из Княгинина) [22, л.6]; 22 сентября сотенный Запольский привел 200 чел.; 24 сентября сотенный Аверкиев доставил 200 чел. [22, л.6]; 26 сентября сотенный Ружевский доставил 350 лукояновских ратников [22, л.6]. «Сверх того, поступило из Макарьевского уезда 247 человек. Итого (к концу сентября поступило - авт.) -1497 человек» $[22$, л.6]. Полковник Ралль с тревогой отмечал, что «число обмундированных воинов во всех сих партиях весьма незначительно и доставление как амуниции, так и провианта происходит чрезвычайно медленно» $[22$, л.6]; вместо многих элементов положенной амуниции «многими вотчиноначальниками (помещиками - авт.) даны были ... партионным офицерам деньги, а именно: на покупку ранца, патронташа, ремней и пряжек по 8 рублей, на пики с древками по 250 копеек, на крест и герб по 50 копеек» $[25$, л.30]. Был случай, когда Ралль вернул обратно ассигнацию в 50 руб., «казавшуюся сомнительною». К тому же имела место организационная неразбериха начального этапа формирования ополчения, что повлекло за собой некоторые проблемы в продовольственном снабжении, в частности, 4-го полка: провиантский «комиссар» Сущев информировал Ралля о невозможности снабжения полка солью по причине, что «... даже к приему оной от вотчинных начальников еще не приступил, потому, что в предписании, данном ему от комитета ничего о соли не упомянуто...» $[22$, л.22]. Медленный, по донесениям Ралля, прием ратников, и проблемы со снабжением, усугубились, на время, невозможностью приема возраставшего количества больных в лысковскую больницу, так как главный лекарь ее «объявил», что не может принимать в больницу без личного приказания Грузинского [22, л.23], но, впрочем, эту проблему быстро разрешили.
Весьма интересным моментом процесса формирования 4-го полка являлись просьбы многих офицеров (на имя командира полка) о перемещении «в свои» роты и батальоны «собственных людей» из других подразделений, т.е., их собственных крепостных, отданных ими же в ратники и попавших в другие части и просьбы эти, по возможности, удовлетворялись [22, л.28]. На 3-е ноября 1812 г. «состояние» формируемого 4-го полка выглядело следующим образом:

«По списку состоит»: полковых начальников-1, батальонных-4, сотенных-17, пятидесятных-28, урядников-19, писарь-1, барабанщиков-27, воинов-2419

«Больных воинов»: в лазарете-13, в околотке-39

«Недостает»: сотенных-3, пятидесятных-10, урядников-157, писарей-23, воинов-70

«Налицо»: полковых начальников-1, батальонных-4, сотенных-15, пятидесятных-24, урядников-17, писарь-1, барабанщиков-нет, воинов-2297

«Больных офицеров»: сотенный начальник Нефедьев $[26$, л.1] «Состояние» полка на 13-е ноября 1812 г.:

«По списку состоит»: полковых начальников-1, батальонных-4, сотенных-13, пятидесятных-27, урядников-24, писарь-5, барабанщиков-37, воинов-2407

«Больных воинов»: в лазарете-16, в околотке-55

«Недостает»: сотенных-2, пятидесятных-10, урядников-150, писарей-21, воинов-28

«Налицо»: полковых начальников-1, батальонных-4, сотенных-16, пятидесятных-25, урядников-20, писарей-5, барабанщиков-нет, воинов-2321

«Больных офицеров»: сотенные начальники Болтин и Пантусов

«Прибыли»: пятидесятные начальники Воинов, Фоглер, Надежин, Тито, Зверев, Карасев, Правиков, Серафимов, Платковский, Редлен, Персон

«Уволен за болезнию»: Нефедьев [26, л.7]

По рапорту от 30 ноября 1812 г.:

«По списку состоит»: полковых начальников-1, батальонных-4, сотенных-18, пятидесятных-26, урядников-27, писарь-5, барабанщиков-37, воинов-2393

«Больных воинов»: в лазарете-16, в околотке-55

«Недостает»: сотенных-2, пятидесятных-13, урядников-151, писарей-20, воинов-21

«Налицо»: полковых начальников-1, батальонных-4, сотенных-18, пятидесятных-22, урядников-23, писарей-4, барабанщиков-нет, воинов-2289

«Прибыли»: «из духовного звания» урядники Е. Сергиевский, А. Иванов, М. Степанов $[26$, л.9]

В декабре 1812 г. пятидесятный Зверев получил приказ о конвоировании 41 чел. французских военнопленных, с чем успешно справился и доставил их в пункт назначения [20, л.1]. 24 декабря 1812 г., перед самым началом похода, списочный состав 4-го полка выглядел следующим образом:

«По списку состоит»: полковых начальников-1, батальонных-2, сотенных-15, пятидесятных-22, урядни- 
ков-124, писарь-5, барабанщиков-37, воинов-1999

«Больных воинов»: в лазарете-нет, в околотке-34

«Недостает»: сотенных-2, пятидесятных-8, урядников- 11 , воинов-41

«Налицо»: полковых начальников-1, батальонных-2, сотенных-14, пятидесятных-19, урядников-120, писарей-4, барабанщиков-37, воинов-1961

«Больных офицеров»: Пантусов, Зверев

Как видно из приведенных данных, накануне выступления полка в поход удалось несколько снизить дефицит офицеров и существенно пополнить ряды урядников, очевидно, «произведением в оные» лиц, в основном, из крестьянской ополченской среды (и, отчасти, среды духовной и дворянской). Налицо было также некоторое снижение количества больных ратников «в лазарете и околотке», а также пополнение рядов барабанщиков [26, л.10].

С 25 сентября по 1 ноября 1812 г., согласно «ведомости о больных», которую представил Грузинскому смотритель лысковской больницы Курганов, в больнице побывали 14 ратников 4-го полка (Д. Рязанов, Я. Чиженков, М. Серов, Н. Цыпленков, П. Горин, Н. Мякишев, С. Касковцов, Ф. Мякишев, М. Баранников, Ф. Григорьев, М. Кашин, А. Широков, Е. Гурьянов, А. Конской), из которых 5 человек были выписаны, а 9 - продолжали лечение [21, л.3]. К середине декабря 1812 г., т.е., ближе к выступлению полка в поход, Ралль представил Грузинскому списки офицеров и нижних чинов, «неспособных следовать в поход». Среди «неспособных» офицеров значились: Львов, Князеделев, Мустафин, Косткин, Сенцов. «Неспособных» воинов насчитывалось 181 чел., которые были «сданы (под командование - авт.) пятидесятному начальнику Косткину...с именными, формулярными и арматурными списками (и) аттестатами на получение жалованья и провианта» [23, лл.3-5]. По рапортам Косткина Грузинскому, положение этой «команды» было достаточно трудным, поскольку «...на вышеописанных воинов провианта в получении не имеется, а посему и вынуждены питаться по развезенным квартирам от жителей ... но оные недовольны...» $[23$, л.6] и просил отпускать воинов, хотя бы на некоторое время, домой «для пропитания», что и было сделано, поскольку уже в следующем рапорте сотенного Львова (позднее принявшего командование над этими людьми), отмечено, что из 181 чел. в отпуску находятся 60 (!) чел. [23, л.9] Среди чрезвычайных, либо заметных происшествий, случившихся в период формирования 4-го полка следует отметить расследование «зажигательства», которое совершил на почве личной мести (либо «на классовой почве») ратник М. Маркелов перед поступлением в ополчение [24, л.569]; предотвращение, в декабре 1812 г., готовившегося массового побега из полка и вероятного совершения конокрадства группой ратников, готовившихся, к тому же, обзавестись фальшивыми паспортами [22, л.48], а также поставленный Раллем перед руководством вопрос о «нерадении к службе» и самовольной отлучке сотенного начальника Панова [22, л.62]. Еще одним заслуживающим внимания эпизодом стало предписание Грузинского (специально для офицерского состава 4-го полка) о прекращении «неумеренных наказаний» ратников в ходе военного обучения [24, л.337]. Среди отрывочных и далеко не полных сведений о походе 4-го полка до назначенных мест в Киевской и Волынской губерниях, известно, что в январе 1813 г. в ходе движения полка «проходя Меленковской уезд (Владимирской губернии-авт.), в деревнях, в которых останавливался вверенный мне полк для ночлегов по назначению провожавших оной земского суда чиновников, а особливо в селе Дмитриевы Горы господина Баташева находились больные, зараженные свирепствующими здесь болезнями и что по замечанию моему, число больных воинов приметно увеличивается...» [22, л.66]. По рапорту Ралля от 7 января 1813 г., «состояние» полка было следующим:

«По списку состоит»: полковых начальников-1, батальонных-3, сотенных-15, пятидесятных-22, урядников-121, барабанщиков-37, воинов-2007, нестроевых-91

«Больных воинов»: в лазарете-23, в околотке-89

«Недостает»: пятидесятных-7, урядников-11, воинов-33

«Налицо»: полковых начальников-1, батальонных-2, сотенных-12, пятидесятных-18, урядников-115, барабанщиков-36, воинов-1895

«Больных офицеров»: Пантусов, Зверев [22, л.17]

По рапорту от 4 февраля 1813 г. о «состоянии» 4-го полка:

«По списку состоит»: полковых начальников-1, батальонных-3, сотенных-15, пятидесятных-22, урядников-121, барабанщиков-37, воинов-2006

«Больных воинов»: в лазарете-46, в околотке-60

«Недостает»: пятидесятных-7, урядников-11, воинов-34

«Налицо»: полковых начальников-1, батальонных-3, сотенных-12, пятидесятных-15, урядников-113, воинов-1896, нестроевых-84

«Больных офицеров»: Пантусов, Пирожков [22, л.9]

В феврале же Раллем были приняты деньги (1610 руб. 40 коп.) $[19$, л.6] от комитета пожертвований на «мясную и винную порцию» для личного состава полка. Действительно, число больных воинов «приметно увеличилось», но еще не достигло своего пика, который, для нижегородского ополчения и ополчений прочих губерний, достигнет в марте-апреле 1813 г., когда первые ополченские подразделения достигнут Киевской и Волынской губерний и завершат первый этап своего похода. Впереди будет долгий заграничный поход и сражения на немецкой земле. 


\section{ЛИТЕРАТУРА}

1. рубов В.И., Николаев Д.А. Вопросы архивоведения и источниковедения в высшей школе//0течественные архивы. 2018. №1. С.116-117

2. Грубов В.И., Николаев Д.А. Вопросы архивоведения и источниковедения в высшей школе//0течественные архивы. 2019. №2. С.129-131

3. Дорофеев Ф.А., Николаев Д.А. Особенности формирования офицерского корпуса в нижегородском ополчении 1812 г.//Вопросы истории. 2020 . №1. C.121-128

4. Дроздов Ф.Б., Николаев Д.А. Народное ополчение 1812 г. и общественный договор//Вестник Нижегородского университета им. Н.И.Лобачевского. 2012. №6 (3). C.95-99

5. Егоров Г.В., Николаев Д.А. Формирование «подвижного магазейна» по снабжению армии в Нижегородской губернии в 1812 г.//Гуманитарные и социально-экономические науки. 2017. №5 (96). С.95-98

6. Кауркин Р.В., Дроздов Ф.Б., Николаев Д.А. Отечественная война 1812 г. Нижегородское ополчение и его участие в заграничных походах $1813-1814$ гг. Н.Новгород: НО ИРИ, 2012. 158 с.

7. Николаев Д.А. Добровольцы в нижегородском ополчении 1812 г.: исторические реалии и историографические мифы//Вестник Нижегородского университета им. Н.И. Лобачевского.2018. №2. С.67-77

8. Николаев Д.А. Заболеваемость офицеров нижегородского ополчения 1812 г. (по материалам официального делопроизводства начала XIX века)// 0боронно-промышленный комплекс России: исторический опыт и современные стратегии. Сборник материалов II Всероссийской научно-практической конференции. 2017. С.96-99

9. Николаев Д.А. Как и чем вооружалось нижегородское ополчение в 1812 году//Военно-исторический журнал. 2019. №2. С.75-79

10. Николаев Д.А. Комплекс документов по вопросам продовольственного и вещевого обеспечения нижегородского ополчения 1812 г.//Торговля, купечество и таможенное дело в России в XVI - XIX вв. Сборник материалов Четвертой международной научной конференции. Редактор-составитель А.И. Раздорский. Редколлегия: В.Н. Беляева [и др.]. 2018. С.345-349

11. Николаев Д.А. Материалы официального делопроизводства по вопросам продовольственного и вещевого обеспечения нижегородского ополчения 1812 г.//Вопросы архивоведения и источниковедения в высшей школе. Сборник статей участников XVI Региональной научно-практической конференции. Под редакцией В.И. Грубова, А.А. Исакова. 2019. С.39-43

12. Николаев Д.А. Некоторые аспекты развития военного производства Нижегородской губернии в начале XIX века (на примере вооружения нижегородского ополчения 1812 г.)//0боронно-промышленный комплекс России: исторический опыт и современные стратегии. Сборник материалов II Всероссийской научно-практической конференции. 2017. С.58-62

13. Хвостова И.А., Николаев Д.А. Инспекторский смотр обмундирования и снаряжения нижегородского ополчения в 1812 г.//Современная наука: актуальные проблемы теории и практики. Серия «Гуманитарные науки». -2017. -№12. -С.58-61

14. Хвостова И.А., Николаев Д.А. Логистические особенности обеспечения нижегородского ополчения 1812 г. на начальном этапе его формирования (сентябрь - октябрь 1812 г.)//Вопросы истории. 2020. №2. С.217-224

15. Хвостова И.А., Николаев Д.А. Страницы истории нижегородского ополчения 1812 г.: проблема «лишнего» оружия//Современная наука: актуальные проблемы теории и практики. Серия «Гуманитарные науки». -2019. -№9. -С.35-37

16. Хвостова И.А., Николаев Д.А. «. . Упражняются. . . в пьянстве и буйстве. . .»: формирование и девиантные особенности походного марша 3-го полка нижегородского ополчения (сентябрь 1812 - июнь 1813 гг.)//История: факты и символы. 2019. №4 (21). С.27-36

17. Хвостова И.А., Николаев Д.А. Формирование и походный марш 5-го полка нижегородского ополчения 1812 г. (сентябрь 1812 - апрель 1813 гг.)//Гуманитарные и социально экономические науки. 2019. №3 (106). С.98-103

18. Хвостова И.А., Николаев Д.А. Формирование и походный марш конного полка нижегородского ополчения 1812 г. (сентябрь 1812 - февраль 1813 гг.)// Гуманитарные и социально экономические науки. 2018. №2 (99). С.115-119

19. Центральный архив Нижегородской области (ЦАНО), Ф.1822, 0п.1, Д.12

20. ЦАНО, Ф.1822, Оп.1, Д.43

21. ЦАНО, Ф.1822, Оп. 1, Д.46

22. ЦАНО, Ф.1822, Оп.1, Д.50

23. ЦАНО, Ф. 1822, Оп.1, Д.79

24. ЦАНО, Ф.1822, Оп. 1, Д.83

25. ЦАНО, Ф.1822, Оп.1, Д.97

26. ЦАНО, Ф.1822, Оп.3, Д.6

( Николаев Дмитрий Андреевич (dmnikolaeff@mail.ru), Дорофеев Федор Александрович (feddor70@mail.ru). Журнал «Современная наука: актуальные проблемы теории и практики» 